\title{
Impact of Non Tariff Measure on Indonesian Cacao Exports
}

\author{
Andi Tenri Darhyati*, Suharno, Amzul Rifin \\ Department of Agribusiness, Faculty of Economic and Management, Bogor Agricultural University \\ *Corresponding author e-mail: anditenridarhyatiAT@gmail.com
}

How to Cite: Darhyati, A.T., Suharno., \& Rifin, A. (2017). Impact of Non Tariff Measure on Indonesian Cacao Exports, Int. J. Agr. Syst. 5(2): 175-184.

\begin{abstract}
Increased awareness of food safety issues has resulted in non-tariff measure in the form of sanitary and phytosanitary, technical barrier to trade applied to various importing countries. The policy is widely applied by various countries on agricultural commodities, especially Cocoa. Cocoa is Indonesia's flagship commodity exported to many countries. The purpose of this research is to analyze the implementation and impact of non tariff measure on Indonesian cocoa exports. The model used in this research is to estimate the result of inventory approach in gravity model. The results show that Sanitary and Phytosanitary policy has an effect on decreasing export value of Indonesian Cocoa while Technical Barrier to Trade has no significant effect. SPS policy is mostly applied to Cocoa Beans while TBT is more applied to processed cocoa. So, Indonesia needs to improve the processing of cocoa beans such as cacao shells, cacao paste, cacao butter, cacao powder, chocolate and other preparations. The government needs to provide socialization to Indonesian cocoa agribusiness entrepreneurs in the implementation of sanitary and phytosanitary policy. Government programs or policies are designed according to the characteristics of SPS and TBT.
\end{abstract}

Copyright (ㅇ 2017 IJAS. All rights reserved.

\section{Keywords:}

Non-tariff measure; sanitary and phytosanitary; technical barrier to trade; gravity model; inventory approach

\section{Introduction}

The decline in tariffs that make the agricultural sector faces a threat because the agricultural market should be open from abroad agricultural commodities. With the existence of such threats, many countries began to increase non-tariff policy in the trade of agricultural commodities. The non-tariff policy is a protection against domestic producers from the competition of foreign-owned products that will reduce the export of countries in trade so that the volume will be reduced until no export occurs. The use of non-tariff measure is increasing as the number of liberal economic cooperation. Non-tariff measure has an important role in international trade in last few years (Disdier and Tongeren, 2010).

The increase of Non-tariff measure and affects the trade became the subject of public debate, especially sanitary and phytosanitary (SPS) and Technical Barrier to Trade (TBT) (UNCTAD, 2016). Awareness increased of food safety issues causing non-tariff measure such as sanitary and phytosanitary measures and technical barriers to trade imposed on exporting countries (Melo et al., 2014; Disdier et al., 2008; Mayeda, 2004; 
Grandslandt and Markusen, 2001). SPS and TBT could have an impact on export value and export volumes (Melo, 2014; Otsuki et al., 2001; Wilson and Otsuki, 2004; Gebrehiwet et al., 2007; Disdier et al., 2008) and have a greater impact when developed countries apply (Melo et al., 2014). The negative impact of non-tariff measure is perceived by developing countries or countries with low income (Swinnen and Vandemoortele, 2011; Yue et al., 2010; Jongwanich, 2009; Chen et al., 2008; Disdier et al., 2008; Henson and Loader, 2001). SPS action refers to actions that affects areas such as substance restrictions, hygiene requirements, or other measures to prevent disease dissemination. It also covers all measures of conformity assessment related to food safety, such as certification, testing and inspection, and quarantine. TBT refers to actions such as labeling and other actions to protect the environment. It also includes conformity assessment relating to technical requirements such as; certification, testing and inspection (UNCTAD, 2016).

SPS and TBT policies are more widely applied to various sectors and more applied to agricultural products. SPS and TBT are applied in various agricultural products from upstream to downstream subsystems. Each country applies SPS and TBT to the exporting country varies. So there needs to be a study on the impact of non-tariff measure majoring in Sanitary and Phytosanitary and Technical Barrier to Trade on the main Indonesian agricultural products, Cocoa.

One of the plantation commodities that contribute to total GDP is Cocoa. Almost all cocoa products used for export are $80.64 \%$. so, it is important to increase production growth. If production decreases then the volume and value of exports will decrease so the foreign exchange will also decrease (Arsyad et al., 2011). Cocoa exported by Indonesia in the form of seeds, cacao shells, cacao paste, cacao butter, cacao powder, chocolate and other food preparations containing cocoa. Cocoa Paste and Cocoa Butter is processed cocoa products began to dominate, no longer the cocoa beans.

Indonesia as the third exporter of the world certainly not easy in doing business in the international market. Especially when the value of cocoa exports increases as shown in the picture. Various obstacles will be faced, especially non-tariff measure. Quality issues become one of the factors inhibiting Indonesian exports. Moreover, exports of cocoa in Indonesia to the United States undergo automatic detention. Indonesian cocoa is considered not reach the requirements set Food and Drug Administration (FDA). The reason to this action, due to the presence of dirt (fifth), fungi, bacteria and insect contamination.

The highest of SPS and TBT application was in cocoa products, namely Sanitary and Phytosanitary as many as 694 acts and Technical Barrier to Trade 337 action (UNCTAD, 2016). This is certainly very worrying because America as the largest consumer of Cocoa. Based on the above explanation, then formulated the problem as follows; How is the implementation of non-tariff Measure by importing countries on exports of Indonesian Cocoa? What is the impact of non-tariff Measure against Indonesian cocoa exports in the International Market? The purpose of this research is to analyze the application of non-tariff measure and its impact to Indonesian cocoa exports.

\section{Materials and Method}

\subsection{Data}

The data used in this study was secondary data. Data came from various WTO, World Bank, Trade Map, time and date, Fx Sauders, international publication and other sources related to the objective of the research. The data studied are cocoa 
commodity (HS 18). This study focused on NTM in the form of Sanitary and Phytosanitary (SPS) and Technical Barrier to Trade (TBT).

\subsection{Method}

The data used in this study was secondary data. Data came from various WTO, World Bank, Trade Map, timeanddate, Fx Sauders, international publication and other sources related to the objective of the research.. The data studied are cocoa commodity (HS 18). This study focused on NTM in the form of Sanitary and Phytosanitary (SPS) and Technical Barrier to Trade (TBT).

\subsubsection{Inventory Approach}

Descriptive analysis is used to provide an overview of NTM policies imposed by export destination countries. Analysis of non-tariff barriers policy was done by the inventors approach that uses a frequency index and the coverage ratio as an indicator. The frequency index is only used to measure the presence or absence of a non-tariff barriers and summarizes the percentage of products in which one or more policy applied (Fugazza, 2013). frequency index shows the percentage of import transactions covered by a number of non-tariff policy for the country of export, while coverage ratio is a percentage of the subject of trade imposed non-tariff policy on the importing country and provides a measure of the importance of import non-tariff policy as a whole. Both indicators are formulated as follows:

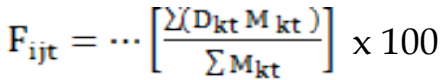

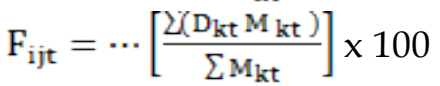

Where:

Fijt = Frequency index exporting country $\mathrm{i}$ to importing country $\mathrm{j}$ in year $\mathrm{t}(\%)$

Dkt $=$ dummy variable indicating whether or not there is one or more non-tariff policy on the product $k$ in year $t$

$\mathrm{MkT}=$ number of product $\mathrm{k}$ with total year of imported amount

Cijt = Coverage ratio exporting country $\mathrm{i}$ to importing country $\mathrm{j}$ in year $\mathrm{t}(\%)$

$\mathrm{VkT}=$ product value $\mathrm{k}$ with total year of imported amount

$\mathrm{j} \quad=$ importing country

$\mathrm{i} \quad=$ exporting country

$\mathrm{k} \quad=$ imported products

$\mathrm{t}=$ the year of non-tariff policy applied

$\mathrm{T}=$ total of year of imported amount to destination country

The values of frequency index and the coverage ratio is in the range of $0-100$. Values of frequency index are getting smaller shows the less of non-tariff policy used by a country, and vice versa. Value coverage ratio over time might indicate fewer products affected coverage of non-tariff policy, while the coverage ratio growing increasingly wide scope shows the affected products non-tariff policies.

\subsubsection{Gravity Model}

Gravity Model was an analytical tool to measure the impact of non-tariff policy in particular SPS and TBT in the export product. The independent variable used in the model design is the export value of Indonesian Cocoa to the main destination country. The independent variables included GDP per capita of the importing country, population of importing country, bilateral economic distance between exporting and importing countries, NTMs (TBT and SPS) enforcement, and real exchange rate. 
The model used in the study to see the effects of non-tariff policies refer to the gravity model refers to Fontagne research model. In this study, using the coverage ratio approach as independent variables. The model was formulated as follows:

Model I:

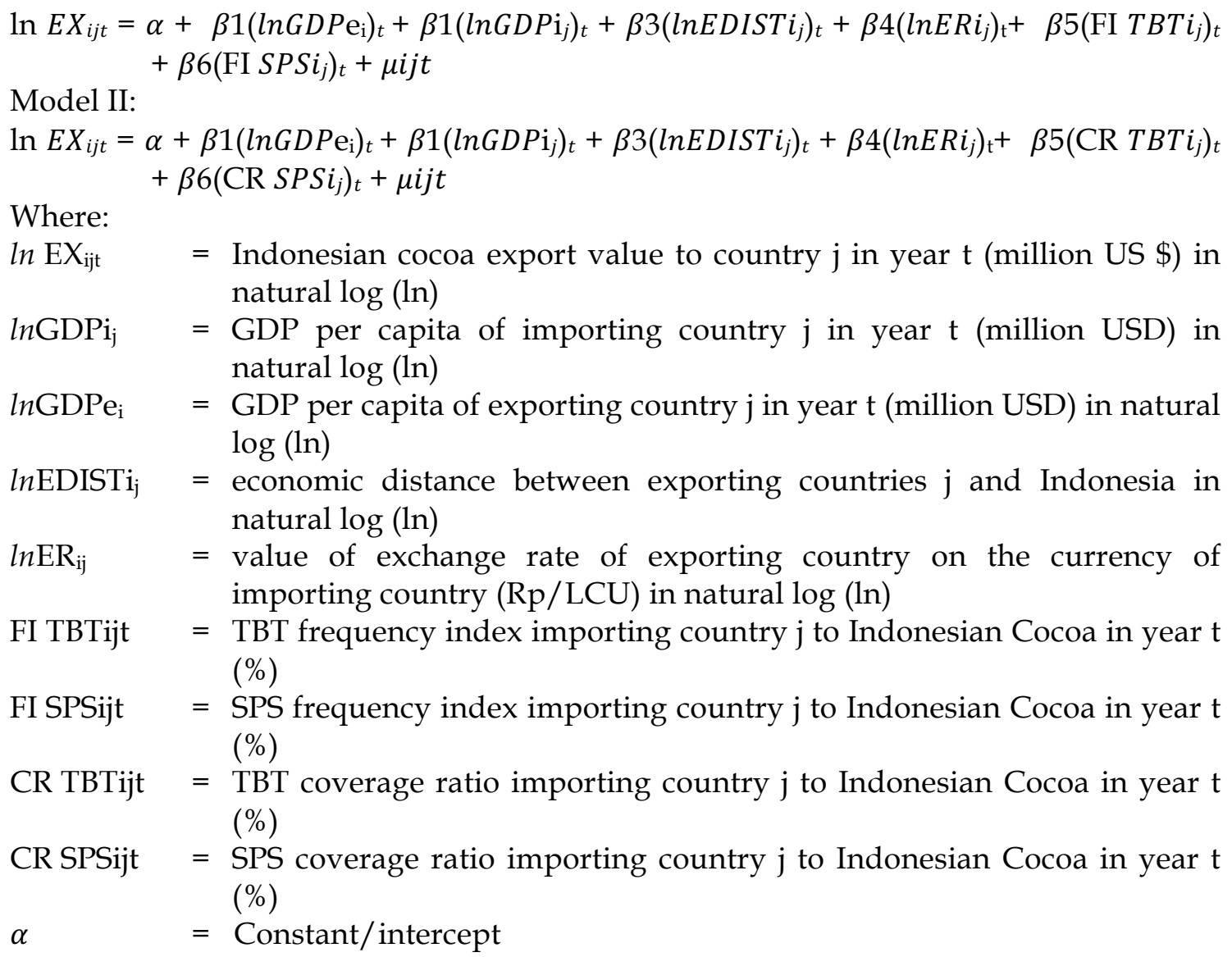

\section{Results and Discussion}

\subsection{Implimitation of Non Tariff Measure}

The decline in tariffs that occur made various countries increase the policy of non tariff measure. Nontariff measure was applied to various countries to protect domestic producers and consumers from various disease outbreaks. Non-tariff measure policy was more applied to agricultural products especially Cacao. Indonesia is one of the largest cocoa exporters in the world. With the non-tariff measure applied, the Indonesian government needs to pay attention to various non tariff measure policies applied by importing countries especially Sanitary and Phytosanitary and Technical Barrier to Trade.

Analysis of non tariff measure implementation by Indonesia cocoa importing country used inventory Approach method with frequency index approach and coverage ratio. Non Tariff Measure in the form of Sanitary and Phytosanitary (SPS) and Technical Barriers to Trade (TBT) imposed by the importing country, Indonesian cocoa are presented in the following table. 
Table 1. Number of NTM applied to Indonesian Cocoa commodity in 2001-2015

\begin{tabular}{lccc}
\hline Country & SPS & TBT & Total \\
\hline USA & 14 & 52 & 66 \\
Canada & 43 & 5 & 48 \\
Japan & 30 & 0 & 30 \\
Thailand & 21 & 8 & 29 \\
Brazil & 3 & 5 & 8 \\
China & 3 & 5 & 8 \\
Malaysia & 2 & 4 & 6 \\
Philipines & 3 & 1 & 4 \\
Mexico & 2 & 1 & 3 \\
\hline Total & 121 & 81 & 202 \\
\hline
\end{tabular}

Source: WTO (2016) processed

Table 1 shows that based on the total amount, the SPS policy is the most applied policy by the Indonesian cocoa importing country. SPS policy applied by the importing country as many as 121 policies that focus on food security and human health while TBT policy as many as 81 policies on food standards and labeling. The countries most widely implemented SPS policies are Canada and Japan (43 policies and 30 policies). The country with the most implemented TBT is America as many as 52 policies. Based on the total policy value, the most widely applied Non Tariff Measure policy is America followed by Canada and Japan.

The composition of SPS and TBT enforcement in export destination countries comprises various policies and each country implements different SPS and TBT policies. The most widely applied SPS policy is the SPS policy on human health and food safety. The most widely applied TBT policies are policies on food standards and labeling policies. Based on HS Cacao code coverage, SPS policy is mostly applied to cocoa beans (HS 1801) by cocoa importing countries while TBT policy is more applied to cocoa processed products (HS 1805 and 1806).

\subsection{Test of Goodness of Fit}

Based on the feasibility test and model fit, the best model estimation was Fixed Effect Model. This model was selected based on Chow Test and Hausman Test results. Chow test was used to select the best model between common effect model and fixed effect model. In model 1 , the result of chow test showed probability value $0.005<0.05$. The probability value in model 2 was generated from the test Chow test shows that $0.0009<0.05$. Both models rejected Ho which means the appropriate model was a fixed effect model model. Furthermore, both models were tested again using Hausman test to choose between fixed effect model with random effect model. The test result on model one showed probability value that was $0.0082<0.05$ and in model 2 showed probability that was $0.0000<0.05$. Both models rejected Ho means the more appropriate model was a fixed effect model. From the test results of Chow test and Hausman test, it was decided to use fixed effect model. 
Table 2. Estimated Results Model 1 and Model 2

\begin{tabular}{lllll}
\hline \multirow{2}{*}{ Independent Variables } & \multicolumn{3}{c}{ Model 1 } & \multicolumn{2}{c}{ Model 2 } \\
\cline { 2 - 5 } Coefficient & Prob & 0.0000 & $4.653808^{* * *}$ & 0.0000 \\
\hline GDP Exporter & $4.665579^{* * *}$ & 0.0000 & $0.184552^{* * *}$ & 0.0000 \\
GDP Importer & $0.185422^{* * *}$ & 0.0033 & $0.065063 * *$ & 0.0035 \\
Economic Distance & $0.066154^{* *}$ & 0.0000 & $-0.20997 * * *$ & 0.0000 \\
Exchange rate & $-0.21853^{* * *}$ & 0.0000 & $1.07224^{* * *}$ & 0.0000 \\
Frequency Index SPS & $1.072694^{* * *}$ & 0.0412 & & \\
Frequency Index TBT & $-0.00069^{* *}$ & 0.4544 & & 0.0224 \\
Coverage Ratio SPS & -0.00023 & & $-0.00054 * *$ & 0.5262 \\
Coverage Ratio TBT & & & -0.00015 & 0.982871 \\
\hline R-Squared & 0.982662 & 0.981937 & 1051.976 \\
Adjusted R-Squared & 0.981716 & & 0.0000 & \\
F-Statistic & 1039.052 & & & \\
Prob (F-Statistic) & 0.0000 & & & \\
\hline Description: & & & \\
\hline
\end{tabular}

Description: *** significant at the real level of $1 \%$

** significant at the real level of $5 \%$

Indonesia's GDP variables per capita had a significant influence on the real level 1\% on Indonesian Cocoa exports. This can be seen from the probability value of Indonesian GDP per capita was smaller than the real level $(0.00<0.01)$. The coefficients of the per capita GDP variable in both models were 0.185422 and 0.184552 . The coefficients in both models were marked positive according to the hypothesis. The meaning of the coefficients in the model 1, each GDP increase per capita in Indonesia amounted to one percent of the export value will increase by 0.18 percent, and vice versa (ceteris paribus). The meaning of the coefficients in model 2, each GDP increase per capita in Indonesia amounted to one percent of the export value will increase by 0.18 percent, and vice versa (ceteris paribus). This could be happened because of GDP as the total income of a country or equal to the total economic population in a national economy. When GDP can increase then the resulting output will increase. As output increases, the ability to produce will increase and people's purchasing power also increases. Each company will spend capital investments by increasing capital or purchasing production equipment for the purpose of replacing or adding capital goods in order to increase production, equitable income utilization of natural and human resources so as to encourage exports. When GDP per capita was high then the ability of purchasing power will be high.

The estimation resulted of Gross Domestic Product (GDP) Per Capita Importer on both models was 0.066 and 0.065 . GDP variable per capita of destination country had positive and significant influence to export value of Indonesian Cocoa. This was indicated by the probability value of variable GDP per capita of destination country was smaller than $1 \%$ real level in both models $(0.00<0.01)$. So that the coefficient of GDP per capita importer variable in model 1 means that any increase in GDP per capita importer by 1 percent, the Indonesian Cocoa export value will increase by 0066 percent, and vice versa (ceteris paribus). This was because when GDP per capita in the destination country increases, it will encourage increased demand for cocoa due to the increase in people's purchasing power. This result was in accordance with research conducted by Dahar (2014) states that Increase in GDP per capita of importing 
countries causes its absorption capacity also increased. This will lead to an increase in imports.

The economic distance used as an independent variable was an approach to export costs (transport costs). The economic distance was one of the quite important conditions in gravity models. The economic distance in both models had a negative and significant influence on the value of Indonesian cocoa exports. The coefficients of economic distance variables in model 1 and model 2 were -0.21853 and -0.20997 . The meaning of the coefficients in model 1, that the further distance of Indonesia with export destination countries by $1 \%$, it will reduce the value of cocoa exports by 0.21853 percent. In model 2, the coefficient means that the greater the distance between Indonesia and export destination countries by $1 \%$, it will decrease the value of cocoa exports by 0.20997 percent. If the economic distance farther then there will be an increase in transportation costs which will eventually increase the price of goods to be traded. Thereby reducing the export of Indonesian Cocoa. This was consistent with the theory of gravity that distance can affect the interaction of the object that was interstate trade. The results obtained also fit the Krugman and Obstfeld (2006) theories that distance can increase transportation costs and other costs such as shipment and time. The result of nominal exchange rate estimation on model 1 and 2 had positive and significant influence on $1 \%$ real level. The coefficients on nominal exchange rate variables in model 1 and model 2 were 1.072694 and 1.07224. That was, if the exchange rate depreciate $1 \%$ then the export will increase by 1.072694 percent (model 1) and 1.07224 percent (model 2). This result was in harmony with Ayvh (2016).

\subsection{Impact of SPS Policy and TBT Policy}

Imposition of non-tariff measure on the importing country both in terms of economic, environmental and health carried out to protect the importing country so that people's lives assured. Non-tariff measure applied will have an impact on the increase in the level of prosperity and well-being of a country. Non-tariff measure most widely applied by importing countries cocoa is the policy of sanitary and phytosanitary and technical barriers to trade.

SPS and TBT policy approach and the index Frequency coverage ratio in the estimation of the two models. SPS Policy estimates and TBT policies in both models showed different results. The estimates of both models showed that SPS can affect Indonesia's cocoa exports while TBT had no significant effect on Indonesian cocoa exports. Approach frequency index and the coverage ratio indicated SPS policy and the significant negative impact of TBT whereas no significant effect and was negative. Both approaches frequency index SPS, TBT index frequency, coverage ratio SPS and TBT coverage ratio showed the value of each coefficient of $0.00069 ; 0.00023 ; 0.00054$; And 0.00015 with a negative sign. This was in line with Athukorala and Jayasuriya (2003) stating that food security standards adopted by developed countries tend to have negative implications on export products of developing countries.

Based on the estimated value of the coefficient of frequency index and the coverage ratio of SPS, it mean that when there was additional frequency and coverage ratio SPS index by $1 \%$, it will cause impairment of cocoa exports amounted to 0.00069 and 0.00054 . This result was in line with Wei et al (2012) which also examines the effect of SPS on tea exports. The results showed that SPS had a negative effect on tea exports. The existence of variations in inter-state policies and the increasingly tight SPS policies imposed by importing countries made importing countries a big challenge. So it was necessary to coordinate the standards through good international cooperation. 
SPS policy had an effect on Indonesian cocoa exports compared to TBT policy which had no effect on Indonesian Cocoa exports. This indicated that Indonesia had been able to comply with TBT policy applied by Indonesia cocoa importing countries. SPS policy applied more lead to food security and human health. Each country implemented policies on the quality of cocoa to be exported, each exported cacao might meet the requirements of banned and restricted chemical substances, requirements on labeling of nutrient content and health claims. In addition, there were also organic handling requirements. These may increase additional costs for the exporting country. The WTO (2012) stated that SPS policy may increase the additional costs of costing in transforming production processes and improving technology. Crivelli and Goeschl (2016) revealed that SPS policy is a trade barrier because it can increase fixed cost of trade. Fixed costs increased due to actions such as certification requirements, testing procedures, inspections and approvals. These requirements were applied by Indonesian cocoa importing countries.

Indonesia often had automatic detention that the rebate on exports of cocoa Indonesia. This was often experienced by Indonesia since 1991 until now. America was the main exporter of Indonesian cocoa which often provide automatic detention in Indonesia, This was because cocoa Indonesia exports unfermented, found the fungus, insect. droppings and other foreign objects. Indonesian cocoa exporters always provided discounts on unfermented cocoa beans. It fell into the category of food standards that were part of sanitary and phytosanitary policies. Sanitary and phytosanitary policies were more applied by importing countries than TBT policies. Although TBT was less and had no effect, TBT policy cannot be ignored. Cocoa Indonesia needs attention because it was one of the leading commodities of Indonesia. Management begun by farmers, government, academia, and others needs to be improved and form an integrated partnership to increase cocoa competitiveness and increase cocoa market.

Nuddin et al. (2015) stated that there are 11 institutions that should be more proactive in increasing cocoa production: (1) Indonesian Coffee and Cocoa Research Institute (ICCRI), (2) Coordination Forum of Garden Management (FKMK) (3) Association of Indonesian Cocoa (ASKINDO), (4) Indonesian Cocoa Farmers Association (APKI), (5) Indonesian Cocoa Industry Association (AIKI), (6) Provincial Plantation Service, (7) Financial Institution, Bank \& Marketing Institution, (9) Forestry and Plantation Department, (10) Extension Officer at District level, and (11) Joined Farmer Group (Gapoktan).

Policies that have been issued by the government need to have an optimal supervision so that the implementation of the policy can be implemented properly such as the improvement of HACCP implementation. Yunus (2016) stated that the application of HACCP principles by the cocoa farmers group to produce fermented cocoa beans will consistently improve the quality and safety of food products, which will increase their bargaining power in the cocoa market

\section{Conclusion}

Based on the description that had been presented in the previous chapters, it can be concluded the following things; The non-tariff measure policy most applied by Indonesia Cocoa importing country was SPS policy of 121 policy while TBT was 81 policy. Countries that applied the most non tariff measure was America. The policies adopted by America were 14 SPS policies and 52 TBT policies. Based on the approach of frequency index and coverage ratio which was estimated into gravity model showed the result that SPS policy had an effect on decreasing export value of Indonesian 
Cocoa. While TBT had no effect. There are some suggestions in the policy determination about the SPS and TBT policies which applied by exporting countries; (1) the government should provide socializations to Indonesian cocoa agribusiness entrepreneurs to overcome the production quality and could fulfill the international standards regarding quality assurance system, the application of technology, and techniques of pest and disease control (2) Indonesia should improve the processing of cocoa beans into cocoa shells, cocoa paste, cocoa butter, cocoa powder, chocolate and other processed product (3) The policies and the government programs should be designed in accordance with the characteristics of SPS and TBT

\section{References}

Arsyad, M., B.M. Sinaga, S. Yusuf, (2011). Analysis of Impact of Tax Policy of ex-ports on Indonesian Cocoa Export Pro-duction Post-Uruguay Round. Journal Sosial Ekonomi Pertanian. 8 (1): 63- 71.

Athukorala, P.C., Jayasuriya, S. (2003). Food Safety Issues, Trade and WTO Rules: A Developing Country Perspective. The World Economy. 26: 1395-1416, DOI: 10.1046/j.1467-9701.2003.00576.x

Ayvh, Tor, Aon. (2016). Pengaruh Tingkat Kurs terhadap Ekspor di Provinsi Sulawesi Utara. Jurnal Berkala Ilmiah Efisiensi, 16(3), ISSN: 0853-6708

Chen, C., Yang, J., Findlay, C. (2008). Measuring the Effect of Food Safety Standards on China's Agricultural Exports. Review of World Economics 2008, 144(1). DOI: 10.1007/s10290-008-0138-z

Crivelli, P., Groeschi, J. (2016). The Impact of Sanitary and Phytosanitary Measures on Market Entry ad Trade Flows. The World Economy. DOI: 10.1111/twec.12283

Dahar, D. (2014). Analisis Dampak Kebijakan Non Tarif Terhadap Kinerja Ekspor Hortikultura Indonesia ke Negara-Negara ASEAN +3. Tesis. Bogor: Institut Pertanian Bogor.

Disdier, A.C., Fontagne, L., Mimouni, M. (2008). The Impact of Regulations on Agricultural Trade: Evidence from SPS and TBT Agreements. Amer. J. Agr. Econ, 90(2):336-350

Fontagne, L., Mimouni, M., Pasteels, J.M. (2005). Estimating the Impact of Environmental SPS and TBT on International Trade. Integration and Trade, 22(3):737

Fugazza, M. (2013). The Economics behind Non-Tariff Measures: Theoretical Insights and Empirical Evidence. Policy Issues in International Trade and Commodities Study Series No.57. UNCTAD: Geneva.

Gebrehiwet, Y., Ngqangweni, S., Kirsten, J.F. (2007). Quantifying the Trade Effect of Sanitary and Phytosanitary Regulations of OECD Countries on South African Food Exports. Agrekon: Agricultural Economics Research, Policy and Practice in Southern Africa, 46(1):1-17, DOI:10.1080/03031853.2007.9523759

Grandslandt, M., Markusen, J. (2001). Standards and Regulations in International Trade A Modeling Approach. Working Paper 8346. online. Available: http://www.nber.org/papers/w8346 [Accessed: 6 Mei 2016]

Henson, S., Loader, R. (2001). Barriers to Agricultural Exports from Developing Countries: The Role of Sanitary and Phytosanitary Requirements. World Development, 29(1): 85 \pm 102 , DOI: 10.1016/S0305-750X(00)00085-1

Jongwanich, J. (2009). The impact of food safety standards on processed food exports from developing countries. Food Policy, 34:447-457, DOI: 10.1016/j.foodpol.2009.05.004 
Krugman, P.R., Obstfeld, M. (2006). International Economics: Theory \& Policy. Boston; Pearson Addison Wesley

Mayeda, G. (2004). Developing Disharmony? The SPS and TBT Agreements and The Impact of Harmonization on Developing Countries. Journal of International Economic Law, 7(4):737-764, DOI: 10.1093/jiel/7.4.737

Melo, O., Engler, A., Nahuehual, L., Cofre, G., Barrena, J. (2014). Do Sanitary, Phytosanitary, and Quality-related Standards Affect International Trade? Evidence from Chilean Fruit Exports. World Development, 54:350-359

Nuddin, A., Yusuf, S., Sulianderi, N.M.V. (2015). An Alternative Model of Cocoa Production Institution: A Solution in Facing Asean Economic Community. International Journal Agricultural system, 3(2): 143-156, DOI: 10.20956/ijas.v3i2.103

Otsuki, T., Wilson, J.S., Sewadeh, M. (2011). What Price Precaution? European Harmonisation of AFlatoxin Regulations and African Groundnut Exports. European Review of Agricultural Economics, 28(2):263-283

Swinnen, J.F.M., Vandemoortele, D. (2011). Trade and the Political Economy of Food Standards. Journal of Agricultural Economics, 62(2):259-280, DOI:10.1111/j.14779552.2011.00294.x

United Nations Conference on Trade Development. (2016). If You Care About Least Developed Countries, Care About Non Tariff Measures.

Wei, G., Huang, J., Yang, J. (2012). The Impacts of Foods Safety Standards on China's Tea Exports. China Economic Review, 23:253-264, DOI:10.1016/j.chieco.2011.11.002

Wilson, J.S., Otsuki, T. (2004). To spray or not to spray: pesticides, banana exports, and food safety. Food Policy, 29:131-146, DOI: 10.1016/j.foodpol.2004.02.003

Yue, N., Kuang, H., Sun, L., Wu,L., Xu, C. (2010). An empirical analysis of the impact of EU's new food safety standards on china's tea export. International Journal of Food Science and Technology, 45:745-750,DOI:10.1111/j.1365-2621.2010.02189.x

Yunus, Muh Ruslan. (2016). Hazard Analysis and Critical Control Points in Cocoa Bean Fermentation. International Journal Agricultural system, 4(1):13-26, DOI: 10.2095/ijas.v4i1.236 